\title{
Practices of Financial and Management Accounting: Evidence fromSmall and Medium-Sized Enterprises of Nepal \\ Gyaneswar Sharma \\ ABSTRACT
}

One of the important factors which determine the performance of a business organization is effective use of financial and management accounting system. In Nepal, very few published evidence on the accounting practices among small and medium sized enterprises (SMEs) is found. In this regards, this study aims to examine the financial and management accounting practices among SMES in Nepal and to investigate perceived usefulness of these reports for decision making process. A survey was carried out using the SMEs in the various nature of business listed by industrial statistics as sampling frame. The findings from the study has provided relevant and useful insights about the current financial and management accounting practices and the level of perceived usefulness of the accounting reports among SMEs. The result of the study indicates that a majority of the SMEs surveyed prepare their accounting reports at least one times in a year. Man agement accounting reports were perceived to be more useful and decision making tool than financial accounting reports. Among the financial accounting reports, profit and loss statement was considered as most useful, followed by balance sheet and cash flow. It also found that there is no significance mean difference of practices of each accounting system across three types of SMES.

Keywords: Financial and management accounting, small and medium-sized enterprises, budgeting, performance evaluation.

\section{Introduction}

Small and medium-sized enterprises (SMEs) have played an important role in the development of the Nepalese economy through their significant contributions in terms of manufacturing outputs and job creations (Ministry of Industry, Commerce and supply, 2013). They represent approximately 51 per cent of the manufacturing firms of Nepal and provided more than sixty-three per cent of total employment in the industry (ibid). SMEs complement the activities of the larger scale industries through the integration into the mainstream of the industrial development by providing the industries with critical parts and components as well as expanding into the international markets. In Nepal, 3,363 SMEs were established which has been generated as total employment of 299,551 (Ministry of Industry, Commerce and supply, 2013).The prevalent Industrial Enterprises Act, 1992- Nepal, which was amended in 1997, has classified industrial enterprises into four categories. According to the prevalent definition of industrial enterprises in Nepal, Medium size business which has investment of more than NRs 100 million in fixed assets and small size business which has fixed assets between NRs. 30 million and NRs. 100 million.

Growth in changing as well as competition a as a result of information and communication technology (ITC), globalization and trade liberalizations has changed the business 
environment internationally as well as on the domestic front (Gorton, 1999). In order to survive and remain competitive, SMEs must respond to these changes in a timely manner. Unfortunately, many SMEs are unable to sustain their positions in long term. Among the factors that are argued to contribute to the failures of SMEs is lack of proper financial management and cost control such as inadequate or inaccurate financial records, inability to manage fluctuating costs and prices effectively, undercapitalization, poor stocks and credit controls, lack of financial planning and unproductive use of assets, which are crucial in determining business performance (Industrial Development Perspective Plan: Vision-2020, (2002). Sound financial management requires good and reliable source of information which could be obtained from adequate, timely and effective financial reporting as well as management accounting and control practices (Simpson \& Koshers, 2002).

The British experiences shows that profit and loss statements balance sheet, and cash flow statement were prepared for yearly tax calculation but production report, variance report and some of the other financial report were infrequently prepared and used (Abdel \& Luther, 2006). Without adequate, effective and timely financial reports and analysis, the SMEs are losing out on the benefits from those practices such as improved monitoring of financial health and progress, improved ability to anticipate fortunes or failures, better assessments of financial risks and greater ease in financial planning and control (Ibid). Most importantly, in the context of SMEs requiring extra capital to grow, regular financial reports can provide indications on their ability to produce steady cash flows and to service debt (Gorton, 1999). Therefore, it has been established that the use of appropriate financial reporting and management accounting practices could be one of the determinants of company survival particularly in SMEs (Mc-Mahon 1998), but in the context of Nepal not much research has been carried out in this area.

\subsection{Relationship between Financial and Management Accounting}

Financial accounting is concerned with the recording of financial transactions and analyzing the effect of such transactions to assist in the development of business decisions. In addition, financial accounting provides information in the form of balance sheets, income statements, and other financial statements to users outside of businesses that are in some way concerned or affected by the performance of the business-stockholders, creditors, lenders, governmental agencies, and other outside users (Narayanaswamy, 2000).

Where as, Management accounting is concerned with providing specialize internal information to managers who are responsible for directing and controlling operations within the organization (Hilton, 2008). Internal information is the basis for planning alternative short- or long-term courses of action and the decision as to which course of action is selected. From this discussion we can draw the following relationship and framework between financial and management accounting.

Figure 1: Relationship between management and financial $\mathrm{A} / \mathrm{C}$ and their users

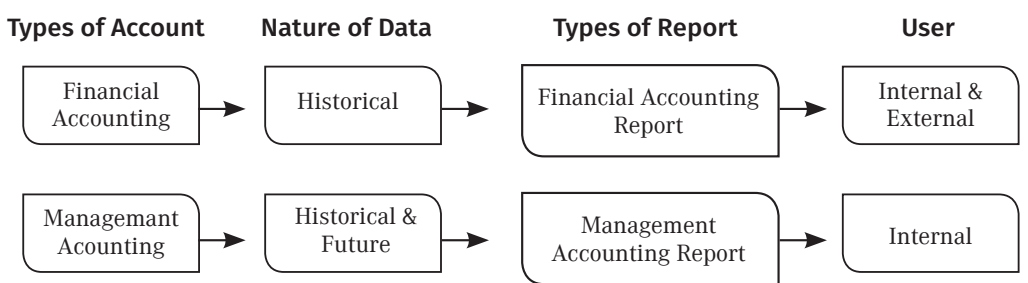




\subsection{Review of Past Studies}

Empirical evidence on accounting practices by SMEs is subjective and irregular (Gorton, 1999). In Australia, there have been a large number of empirical studies conducted on SMEs such as McMahon and Davies (1998), Kitching and et al. (2001) and others. These studies investigate the types of financial reports produced by SMEs, the frequency of their preparation, and their perceived usefulness for management purposes. The findings indicate that financial reports for SMEs are prepared predominantly by external accountants at annual intervals, and they normally comprise just the balance sheet and the profit and loss statement (Gorton, 1999).

The content and presentation of financial reports appear to be greatly influenced by taxation and corporate statutory reporting requirements. Gorton (1999) cited a study by Nayak and Greenfield (1994) on 200 manufacturing firms employing less than ten people in the U.K. which provides evidence that only one third of business formally monitored profits and applied any form of budgeting. Collis and Jarvis (2002) examined private limited companies in the UK. Their findings show that 57 per cent of the respondents had a computerized accounting system and 25 per cent had a partly computerized system suggesting moderate level of sophistication of accounting system.Studies were conducted in various countries to examine the usefulness of accounting reports within the context of SMEs, for examples, McMahon $(1998,2001)$ in Australia, Collis and Jarvis (2002), Gorton (1999) and Nayak and Greenfield (1994) in the UK; and Hopper et al. (1999) on small and medium size Japanese companies. These studies found evidence that financial reports are not considered particularly useful for decision making purposes by SMEs owner-managers. These studies also found that there is limited usage of financial and management accounting reports by SMEs.

\section{Problems and Objectives}

In the current Nepalese business environment, firms are faced with intensifying competition locally and globally, and fast changes in customers and technologies (Sharma, 2012). In this environment it is vital that small and medium enterprises be equipped with appropriate and modern financial and management accounting practices in order for them to survive and remain profitable. One of the factors that determine the performance of a business organization is effective use of financial and management accounting reports. In this connection, this study has try to examine the practice level of financial and management accounting among SMEs and it also further investigates the level of perceived usefulness of financial and management accounting reports.

The result of this study provides information on the extent of financial and management accounting practices as well as perceived usefulness of accounting reports for decision making process. Based on these findings, further research can be carried out to investigate whether accounting practices and performance are related. The information on SMEs' accounting practices and performance would provide important insights and inputs especially to the private as well as government organizations for evaluating whether further assistance could be provided to the SMEs.

\section{Data and Methods}

This study has stand on exploratory research methodology in examining the practices of the management and financial accounting parameters. The population of this study 
comprises manufacturing, trading and service sectors SMEs which were situated in Kathmandu valley. Sample of SMEs were selected randomly using directory of industrial statistic 2012/13. The respondents of sample group were manager, director and chief accountant position as they are well known of the information of the SMEs.

A structured questionnaire survey was used to collect the information for the target respondents. It contains basic information with eight statements using a four point Likert-Like scale. Eighty- two questionnaires were sent to the respondents and it took approximately 1 month for the distribution and collection of the questionnaire. Seventy questioners were returned, thus the response rate was equivalent to $85 \%$. The collected data were interpreted and compared with the help of different types of statistical tools using SPSS. The calculated Cornbach's alpha value is 0.71 , which describes and estimates the internal consistency and reliability of summated scale is satisfactory. Thus, it is claimed that the instruments used in this research is reliable enough.

\section{Discussion and Analysis}

\subsection{Financial Accounting Practices}

The result of the following table no. 1 shows that all the SMEs prepare balance sheet, profit and loss account and cash flow statement. Apart from the main financial statements, the SMEs also prepared fixed asset record and inventory analysis report. The individual financial accounting report, as reflected by the below given statistic, 20 per cent of the total SMEs prepare monthly profit and loss statement, followed closely by balance sheet with 13 per cent. Profit and loss statement allows the management to measure the profitability of their business undertakings and balance sheet will allows management to monitor their net asset balances.

Table 1: Frequency of preparation of financial accounting reports

\begin{tabular}{|l|c|c|c|c|}
\hline \multirow{2}{*}{ Financial Accounting Report } & \multicolumn{3}{|c|}{ Frequency of Reporting } & Total \\
\cline { 2 - 5 } & Quarterly & $\begin{array}{c}\text { Semi- } \\
\text { annually }\end{array}$ & Annually & $100 \%$ \\
\hline Profit and Loss Account & $20 \%$ & $40 \%$ & $40 \%$ & $100 \%$ \\
\hline Balance Sheet & $13 \%$ & $40 \%$ & $47 \%$ & $100 \%$ \\
\hline Cash Flow Statement & $13 \%$ & $7 \%$ & $80 \%$ & $100 \%$ \\
\hline Inventory Analysis & 0 & $20 \%$ & $80 \%$ & $100 \%$ \\
\hline Fixed Assets Record & 0 & 0 & $100 \%$ & $100 \%$ \\
\hline
\end{tabular}

With regard to annual accounting reports, cash flow statement takes the lead with 80 per cent SMEs prepared balance sheet annually. Requirements of accounting standards for companies to prepare annual financial statements might be the reason for the results. Balance sheet is second place with 47 per cent which might show that SMEs are more concerned with cash conditions and financing requirements as compared to profit and loss statement which comes third with only 40 per cent of respondents preparing it. From the study, there was little evidence that SMEs were producing reports on quarterly and semiannually basis. For example, only 40 per cent of respondents stated that they produce balance sheet semi annually, and even fewer $(20 \%)$ stated that they produce balance sheet 
quarterly. Apart from the main financial accounting reports inventory analysis and fixed asset record are also prepared by the SMEs but to a lesser extent of frequency. Fixed assets record is prepared annually (100\%). Inventory analysis, in contrast, is mainly produced annually $80 \%$ and only under 20\% semiannually and no in quarterly time basis.

\subsection{Management Accounting Practices}

The table 2 displays that management accounting reports studied include budgets and cash budget, variance analysis, production / purchase budget, and cost volume profit (CVP) analysis. The findings as displayed in the following table shows that among the management accounting reports, most of the respondents are prepared variances analysis at quarterly (54\%), semiannually (33\%) and 13\% as annually basis. The CVP analysis and production budget are also prepared quarterly, semiannually and annually basis. But talking about cash budget is prepared in semiannually and annually basis. But the budget is prepared only at once a year. This shows that most of the respondents are not more conscious to prepare the budget and cash budget with compare to CVP analysis, variance analysis and production/ purchase budget.

Table 2: Frequency of preparation management accounting reports

\begin{tabular}{|l|c|c|c|c|}
\hline \multirow{2}{*}{$\begin{array}{c}\text { Management Accounting } \\
\text { Report }\end{array}$} & \multicolumn{4}{|c|}{ Frequency of Reporting } \\
\cline { 2 - 5 } & Quarterly & $\begin{array}{c}\text { Semi- } \\
\text { annually }\end{array}$ & Annually & Total \\
\hline Budget & 0 & 0 & $100 \%$ & $100 \%$ \\
\hline Cash Budget & 0 & $8 \%$ & $92 \%$ & $100 \%$ \\
\hline Production/Purchase Budget & $33 \%$ & $47 \%$ & $20 \%$ & $100 \%$ \\
\hline CVP Analysis & $7 \%$ & $20 \%$ & $73 \%$ & $100 \%$ \\
\hline Variances Analysis & $54 \%$ & $33 \%$ & $13 \%$ & $100 \%$ \\
\hline
\end{tabular}

\subsection{Preparation of Financial and Management Accounting Report}

The preparation financial and management accounting report through computerized or manually is also play a vital role in the organization. Because the adaptation of computerized system indicate how companies are familiar and close with new technology. The following table 3 shows 20\% respondent prepare their financial and management accounting report through computer basis but reaming 80\% companies prepare report through both using manually and computerized system. It indicates that still Nepalese companies are not fully adapted with sophisticated technology.

\subsection{Objective of Preparation of Accounting Report}

There are several reasons to prepare financial statement for all types of company. In this regards researcher has asked to respondent to rank why they prepare financial report. From the given table 4 shows that more than half i.e. 53 percent respondents prepare financial report for submission in tax office. Thirty four percent respondents said that they prepare financial report as know the financial position of the company. And thirteen 
percent respondents have said that they prepare financial report to make decision in the company. It also conclude that first, second, and third priority for preparation of financial report of company is submission in tax office, know the financial position and to make decision respectively.

Table 3: Preparation of accounting reports

\begin{tabular}{lc}
\hline Preparation of Financial \& Management Accounting Report through & Percent \\
\hline Computerized & $20 \%$ \\
\hline Both (Computerized and Manually) & $80 \%$ \\
\hline Total & $100 \%$ \\
\hline
\end{tabular}

Table 4: Objectives of preparation financial accounting reports

\begin{tabular}{lccc}
\hline Purpose of Financial Accounting Reports & Frequency & Percentage & Rank \\
\hline To submission in tax office & 8 & $53 \%$ & 1 \\
\hline To make decision & 2 & $13 \%$ & 3 \\
\hline To know financial position & 5 & $34 \%$ & 2 \\
\hline Total & 15 & $100 \%$ & \\
\hline
\end{tabular}

\subsection{Perceived Usefulness of Accounting Reports}

In measuring perceived usefulness of accounting reports, the respondents were asked to rate the level of usefulness of accounting reports for decision making on a Likert scale of 1 as least useful to 4 almost useful.

Table 5: Usefulness of accounting report

\begin{tabular}{|l|c|c|c|c|}
\hline Accounting Reports & Mean & SD & Min & Max \\
\hline Profit and Loss a/c & 3.70 & .61 & 2 & 4 \\
\hline Balance sheet & 3.67 & .48 & 3 & 4 \\
\hline Cash flow statement & 3.47 & .64 & 2 & 4 \\
\hline Budget & 3.67 & .48 & 3 & 4 \\
\hline Cash budget & 3.20 & .41 & 3 & 4 \\
\hline Variance analysis & 2.93 & .59 & 1 & 4 \\
\hline
\end{tabular}

When researcher asked to rate on the usefulness of each financial and management accounting reports, the above table 5 exhibits that profit and loss statement was ranked first with mean value 3.30 and standard deviation of 0.67 , followed by balance sheet with mean value of 3.67 and standard deviation of 0.48 . Cash flow placed in third position 82 
which has mean value of 3.47 with standard deviation of 0.64 . This is fact that profit and loss account and cash flow statements were ranked the highest in terms of usefulness (mean values above 3.70) indicates the importance placed on profitability and controlling cash by the SMEs, where the previous research (Birley \& Niktari, 1995) also found and suggests to the same result to success and survival of a small business.

On the other hand, management accounting reports comprising mean value of preparation budget is 3.67 with standard deviation of 0.48, preparation of cash budget's mean value is 3.2 with standard deviation of 0.41 and variances analysis having the mean value of 2.93 with 0.54 as standard deviation were considered as occupying the first, second and third place ranking, respectively. This is fact that preparation of budget was ranked the highest in terms of usefulness (mean value above 3.67) which, indicates the importance placed on controlling and allocation the company's resources by the SMEs.

\subsection{The Emphasis on Management Accounting Practices}

The researcher has asked to SMEs regarding the degree of significance and regularity uses of accounting system for the business using three point likert-scale on the five major points of accounting criteria. The following table 6 displays that the accounting system are used to obtain the necessary information for decision making by SMEs. More specifically, accounting system has been used for collection of information to make decision having the mean value of 3.52 with 0.45 as sd. from the degree of significance perspective. It has also ranked at 1 st position under the frequently uses rate of accounting techniques criteria with mean value of 3.08 and 0.62 as sd. The statement of decision making perspective is positioned at first rank from these two aspects. The SMEs have been using different types of accounting techniques as for performance evaluation tool. They also consider that these performance techniques are used and again considered moderate significantly with ranked at 2 nd position from both perspectives. The mean value of the use rate of accounting techniques and the degree of significance of accounting are 2.30 and 2.42 with sd of 0.06 and 0.20 respectively.

Table 6: Comparison of descriptive data of significance and use of extent of accounting techniques

\begin{tabular}{|l|c|c|c|c|c|c|}
\hline \multirow{2}{*}{$\begin{array}{c}\text { Significance and Uses Rate of } \\
\text { Accounting System Criteria }\end{array}$} & \multicolumn{4}{|c|}{$\begin{array}{c}\text { Degree of significance of } \\
\text { accounting system }\end{array}$} & \multicolumn{3}{c|}{$\begin{array}{c}\text { How often does SMEs use } \\
\text { accounting systems? }\end{array}$} \\
\cline { 2 - 8 } & Mean & SD & Rank & Mean & SD & Rank \\
\hline Information for decision making & 3.52 & 0.45 & 1 & 3.08 & 0.62 & 1 \\
\hline Performance evaluation & 2.30 & 0.06 & 2 & 2.42 & 0.20 & 2 \\
\hline Budgeting & 1.83 & 0.95 & 3 & 1.80 & 0.71 & 4 \\
\hline Costing system & 1.69 & 0.63 & 4 & 1.98 & 0.52 & 3 \\
\hline Strategic analysis & 1.25 & 0.05 & 5 & 1.02 & 0.08 & 5 \\
\hline
\end{tabular}


The budgeting technique of accounting system has been ranked as 3rd position under the degree of significance having mean value of 1.83 with 0.95 as sd. But it has been ranked on 4th position having 1.98 as mean score 0.52 as sd under the criteria on frequency use of accounting system. The costing system has been ranked 4th position under the degree of significance of management accounting techniques with mean score of 1.69 and sd of 0.63. Where, it has ranked as 3rd position under the how frequently use of accounting system. Strategic analysis technique is one of the important parts of management accounting system. It is not widely used by SMEs and ranked as 5th position under both criteria with less mean score.

\subsection{Practice of Accounting System among SMEs}

Above literature shows that the practices of management accounting and financial accounting are differ in companies' type and practices of accounting depend upon nature of companies. Here, researcher has tested this fact as hypothesis whether the accounting system practices are differ among sole trading, partnership and private limited SMEs.

Table 7: Analysis of variances (anova) test on accounting practices of smes type

\begin{tabular}{|c|c|c|c|c|c|}
\hline Accounting System & & $\begin{array}{l}\text { Sum of } \\
\text { Squares }\end{array}$ & Df & $\mathrm{F}$ & Sig. \\
\hline \multirow[t]{3}{*}{ Costing System } & Between Groups & 35.17 & 2 & 0.57 & \multirow{3}{*}{0.568} \\
\hline & Within Groups & 2099.02 & 68 & & \\
\hline & Total & 2134.19 & 70 & & \\
\hline \multirow[t]{3}{*}{ Budgeting } & Between Groups & 87.74 & 2 & 1.359 & \multirow{3}{*}{0.264} \\
\hline & Within Groups & 2195.24 & 68 & & \\
\hline & Total & 2282.98 & 70 & & \\
\hline \multirow{3}{*}{$\begin{array}{l}\text { Information for Decision } \\
\text { Making }\end{array}$} & Between Groups & 20.08 & 2 & 0.463 & \multirow{3}{*}{0.631} \\
\hline & Within Groups & 1475.40 & 68 & & \\
\hline & Total & 1495.49 & 70 & & \\
\hline \multirow[t]{3}{*}{ Performance Evaluation } & Between Groups & 0.56 & 2 & 0.057 & \multirow{3}{*}{0.945} \\
\hline & Within Groups & 340.75 & 68 & & \\
\hline & Total & 341.32 & 70 & & \\
\hline \multirow[t]{3}{*}{ Strategic Analysis } & Between Groups & 17.26 & 2 & 1.038 & \multirow{3}{*}{0.360} \\
\hline & Within Groups & 565.66 & 68 & & \\
\hline & Total & 582.93 & 70 & & \\
\hline
\end{tabular}

From above table 7 shows that the p-value of the t-test of each management accounting and financial accounting system is high as compared to the 5 percent level of significance. Therefore, the alternative hypothesis has been accepted and it can be concluded that there is no significance mean difference of practices of each accounting system across the three SMEs. 


\section{Conclusions and Recommendations}

The findings of this study reveal that financial and management accounting practices in the SMEs are relatively contemporary. The results provide evidence that the majority of companies prepare financial and management accounting reports such as profit and loss, balance sheet, and cash flow statements, CVP analysis, variance analysis, and budget on regular basis and there were adequate evidence to suggest the high use of completely computerized accounting system. In terms of usefulness of accounting reports, management accounting reports are considered to be more useful than financial accounting reports. It also found that there is no significance mean difference of practices of each accounting system across three types of SMEs. Future research can be conducted to explore further the accounting practices among SMEs in other sectors such as the service industry. In addition, studies can also be carried out to investigate the relationship between accounting practices and performance. In future it can also be undertaken to identify problems and areas of improvements which can be used by the private and government agencies to formulate policies to ensure existence of SMEs in Nepal.

\section{BIBLIOGRAPHY}

Abdel K. M., \& Luther, R. (2006). Management accounting practices in the british food and drinks industries. British Food Journal, 10(5), 336-357.

Birley, S., \& Niktari, N. (1995). The failure of owner-managed businesses: the diagnosis of accountants and bankers. ICAEW, London, 4(6), 24-49.

Collis, J., \& Jarvis, R. (2002). Financial information and the management of small private companies. Journal of Small Business and Enterprise Development, 9(2), 10010 .

Gorton, M., (1999). Use of financial management techniques in the uk-based small and medium sized enterprises: empirical research findings. Journal of Financial Management \& Analysis, 12(1), 56-64.

Hilton, R. W. (2008). Managerial accounting (7th ed.). New York: Mc-Graw-Hill.

Hopper, T., Koga, T., \& Goto, J. (1999). Cost accounting in small and medium sized Japanese companies: An exploratory study. Accounting and Business Research, 30(1), 7386.

United Nations Industrial Development Organization. (2002). Industrial development perspective plan: vision-2020. A Strategy Paper, Project NC/NEP/00/009. Kathmandu: United Nations Industrial Development Organization.

Kitching, J., Curran, J., \& Lightfoot, G. (2000). The use of quantitative and qualitative criteria in the measurement of performance in small firms. Journal of Small Business and Enterprise Development, 7(2), 123-34.

McMahon, R. G. P. (1998). Financial reporting practices of Australian manufacturing SMEs. Finance and Small Business Management, 12(3), 24-37). 
Ministry of Industry, Commerce and Supply. (2013). Industrial statistic 2012/13. Kathmandu: Department of Statistics.

Narayanaswamy, R. (2000), Financial accounting: a managerial perspective (2nd ed.). New-Delhi, Prentice-Hall of India.

Nayak, A., \& Greenfield, S., (1994). The use of management accounting information for managing micro-businesses. Finance and the Small Firms, 6(4), 23-34.

Sharma, G. (2012). Management accounting practices and manufacturing strategy: The role and use of management accounting system. The Nepalese Management Review, 15(1), 147-154.

Simpson W. G., \& Kohers T. (2002). The link between corporate social and financial performance: Evidence from the banking industry. Journal of Business Ethics, 35(1), 97-109. 